\title{
Profitability of Small Scale Vegetable Production in Southern District, Botswana
}

\author{
Sekgopa T. Kealeboga (Correspondence Author), Lagat K. Job \\ Department of Agricultural Economics and Agribusiness Management \\ Egerton University, Kenya \\ E-mail: sekgopataboka@gmail.com \\ Tselaesele M. Nelson \\ Department of Agricultural Economics, Education and Extension \\ Botswana University of Agriculture and Natural Resources, Botswana
}

Received: October 24, 2016 Accepted: November 25, 2016 Published: January 10, 2017

doi:10.5296/jas.v5i1.10199

URL: http://dx.doi.org/10.5296/jas.v5i1.10199

\begin{abstract}
Government determination to eradicate extreme poverty and food insecurity among Batswana through small scale vegetable production program appears not to transform their economic stance. Rural households that are part of Poverty Eradication Programme were investigated to determine if backyard gardens were profitable enough to improve incomes, reduce extreme poverty, and increase food security. The study aimed at analysing profitability and identifying factors that affect profitability of backyard gardening. Multi-stage sampling technique was used to collect data from 100 rural households who are part of the backyard garden scheme. Data was analysed using descriptive statistics, gross margin analysis and regression analysis. Results indicated that backyard gardening was a viable activity though profitability was affected by amount of fertilizer applied, market availability and area planted. Beneficiaries indicated that the production and marketing constraints they faced included pests and diseases, lack of water, lack of market and poor prices. Program leaders must recognize the production and marketing constraints themselves as well as plan for the possibility that continual financial support for investment in the initial years of operation.
\end{abstract}

Keywords: Botswana, Vegetable profitability, Backyard gardening, Production constraints, Marketing constraints 


\section{Introduction}

At the time of independence in 1966, Botswana was classified as one of the ten poorest countries but presently it is categorized as an upper middle income country (Maipose, 2008). Despite achieving such economic growth, the country still has socio economic challenges including poverty. Results from the Botswana Core Welfare Indicator Survey (BCWIS) of $2009 / 10$, revealed that poverty head count rate stood at $20.7 \%$ with rural poverty at $24.3 \%$ which is relatively high for an upper middle income country. The spread of poverty is geographical with some areas severely affected than others. Botswana's aspiration is to surpass the Sustainable Development Goal target of reducing extreme poverty by half by 2030 (MOPAPA, 2015).

In order to achieve this goal, the government introduced several initiatives aimed at improving livelihoods of Batswana by addressing all aspects of poverty. These include among others Strategic Framework for Community Development in Botswana of 2010, Young Farmers Fund, Economic Diversification Drive, Revised National Policy on Destitute Persons of 2002 and the Poverty Eradication Programme (PEP). PEP was introduced with the aim of attaining food security and minimum sustainable livelihoods amongst disadvantaged individuals and/or families. The backyard garden scheme was introduced towards the end of 2009 as part of the packages of PEP and is a government initiative through which individuals were identified and funded for a backyard garden (Basimane, 2014). Beneficiaries are given inputs such as irrigation systems (water tank, drip irrigation pipes), seeds, fertilizer, tools (spade, garden fork and rake), gum tree poles and net shading all amounting to maximum grant of $\mathrm{P} 12500(\mathrm{P}=$ Pula, Botswana currency $\mathrm{P} 1=0.097 \mathrm{US} \$)$.

According to Torimiro et al. (2015) the types of vegetables that are mostly grown in the gardens are spinach (Spinacea oleracea L.), onion (Allium cepa L.), beetroot (Beta vulgaris L.), carrot (Daucus carota L.), rape (Brassica napus L.), choumolliar ( Brassica oleracea L.), green pepper (Capsicum annum L.) and tomato ( Solanum lycopersicum L.). Backyard farming contributes to food security by assuring the provision of food in fresh form to satisfy the immediate calorie and nutritional needs of the household (Ojo, 2009). Ditedu (2015) stated that backyard gardens were started with the aim of making sure that households were self-sufficient in fresh vegetables and they sell the surplus to their neighbours or through wet markets thus the gardens are found in residential areas and measure approximately $30 \mathrm{~m}$ by $10 \mathrm{~m}$. The intention of this study was to analyze the profitability of small scale vegetable production by rural households. Specifically the study sought to evaluate profitability of backyard gardens, identify factors affecting profitability of vegetable production, marketing and production constraints faced by beneficiaries of the backyard garden scheme.

\section{Literature Review}

There are many methods that can be used to determine profitability of an enterprise as well as identify factors that influence profitability. Some of the methods include gross margin analysis, value of production and total revenue. However gross margin appears to be a common method used to determine profitability, this method of determining profitability has been used in many studies. 
Gross margin is the difference between the value of output and the total variable costs directly associated with the production of that output (Rural Solution SA, 2015). Previous researchers (Adeyemo et al., 2010) calculated gross margin by subtracting the total variable costs from gross revenue. In such studies, gross margin was assumed to be equal to farm net income because fixed costs were not included (Adeyemo et al., 2010).

Ahmad et al. (2005), while studying factors affecting the profitability and yield of carrot production included a partial budgeting model that was used to determine profitability of carrot growing. This methodology included a gross margin analysis which was used to determine the costs of various inputs and the profitability of carrot cultivation. According to Ahmad et al. (2005) the gross margin analysis was used because of its accuracy in estimating profit and factors affecting yield were determined by carrying out a regression analysis. In another study done on profitability of sorghum farming in Tanzania, gross margin analysis was done in which total variable costs were subtracted from total revenue (Erbaugh, 2008). Regression model was then carried out in this study in order to test factors that might have influenced gross margin and hence profitability of sorghum production.

In another study done on the performance and profitability of the banana sub-sector in Uganda by Bagamba et al. (1998), gross margin analysis was used to determine the profitability of banana production. The gross margin analysis involved cost-benefit trade-offs where total variable costs were subtracted from total revenue. Yield of bananas was regressed against variables thought to be influence farmers decisions to invest in agricultural production (Bagamba et al., 1998).

From these studies the most accurate and common method of estimating profits is gross margin analysis, whereas the most common method of identifying factors that influence profitability is multiple regression in which gross margin is regressed on different factors expected to affect profitability.

\section{Methodology}

\subsection{Research Design}

Cross-sectional research design was used in the study with an aim of evaluating profitability of small scale vegetable production in Botswana.

\subsection{Sampling Procedure}

The sample was of the study was derived from a list of rural households that are beneficiaries of the backyard garden program in Botswana. In order to control selection errors, an up-to date list of beneficiaries was obtained from the local extension officer in the Department of Crops. Multi-stage sampling technique involving purposive and random sampling was used to draw a sample of 100 rural households using Yamane (1973) method of determining sample size.

Leafy vegetable (spinach, rape and choumolliar), cabbage, carrots, onions, tomatoes, green peppers and beetroots were studied. These were the vegetables that are produced in major proportions and were in constant supply in the market (Torimiro et al., 2015). 


\subsection{Data Collection}

A structured questionnaire was administered to sampled rural households using of face to face personal interviews. The questionnaire was reviewed by experts in the Department of Agricultural Economics and Agribusiness Management (Egerton University) to establish validity of content. Questionnaires were pretested using farmers that were not part of the sample and a final questionnaire was prepared using responses obtained from the farmers.

\subsection{Data Analysis}

The study used both descriptive statistics and econometric model in analyzing data. Descriptive statistics included means, percentages, standard deviation and frequencies. A multiple linear regression model was used to analyze factors affecting profitability.

\subsection{Analytical Framework and Empirical Models}

\subsubsection{Viability of backyard gardening}

Gross margin analysis was used to determine the viability of the gardening activities therefore the analysis was carried out for leafy vegetables, green pepper, tomatoes, onions, carrots, cabbage and beetroots. The model for calculating the gross margin was specified as:

$$
G M=Q_{i} P_{i}-X_{i} P_{x i}
$$

Where GM is the gross margin, Qi is the quantity of output of crop i produced, Pi is the price of output, $\mathrm{Xi}$ amount of input $\mathrm{i}$ used and Pxi price of input $\mathrm{i}$. Even though the gross margin is an important analytic tool to assess the profitability of different farming enterprises, it has a number of disadvantages (Forestry, 2009). These are:

- There is no inclusion of fixed costs in the analysis. This incomplete analysis may lead to wrong conclusions.

- Gross margin analysis does not take into account the possible environmental and social effects that may arise due to different types of technology or crops grown.

- The results of a gross margin analysis are valid for the season under consideration; therefore, they may be not useful for other recommendations.

\subsubsection{Factors affecting profitability of backyard gardening}

Analysis of the factors affecting profitability of backyard gardening was done using multiple regression analysis. Gross margin per hectare was used as a proxy for profitability. The model was specified as:

$$
\begin{aligned}
& Y=\beta_{0}+\beta_{1} X_{1}+\beta_{2} X_{2}+\beta_{3} X_{3}+\beta_{4} X_{4}+\beta_{5} X_{5}+\beta_{6} X_{6}+\beta_{7} X_{7}+\beta_{8} X_{8}+\beta_{9} X_{9}+ \\
& \beta_{10} X_{10}+\beta_{11} X_{11}+\beta_{12} X_{12}+\beta_{13} X_{13}+\beta_{14} X_{14}+e_{i}
\end{aligned}
$$

Where $\mathrm{Y}$ represents yield of vegetables produced, $\beta_{0}$ is the constant, $\beta_{\mathrm{i}}$ is estimated 
coefficients of the explanatory variables, $\mathrm{X}_{\mathrm{i}}$ is explanatory variables and $\mathrm{e}_{\mathrm{i}}$ is the disturbance term.

The explanatory variables hypothesized to have a relationship with the dependent variable and their expected signs are presented in Table 1.

Table 1. Description of the independent variables used in the productivity model

\begin{tabular}{|l|l|l|l|}
\hline Variables & Coding system & Category & Expected sign \\
\hline $\mathrm{X}_{1}=$ Age of the beneficiary & Number of years & Continuous & - \\
\hline $\mathrm{X}_{2}=$ amount of fertilizer applied & Number of kilograms & Continuous & + \\
\hline $\mathrm{X}_{3}=$ area planted & Number of hectares & Continuous & + \\
\hline $\mathrm{X}_{4}=$ Alternative income source & 1 if available, 0 if unavailable & Dummy & - \\
\hline $\mathrm{X}_{5}=$ Major constraint & 1 if available, 0 if unavailable & Dummy & - \\
\hline $\mathrm{X}_{6}=$ Livelihood threat & 1 if available, 0 otherwise & Dummy & - \\
\hline $\mathrm{X}_{7}=$ Labour source & Man days & Continuous & + \\
\hline $\mathrm{X}_{8}=$ Market constraint & 1 if available, 0 otherwise & Dummy & - \\
\hline $\mathrm{X}_{9}=$ Production constraint & 1 if available, 0 otherwise & Dummy & - \\
\hline $\mathrm{X}_{10}=$ Market availability & 1 if available, 0 otherwise & Dummy & + \\
\hline $\mathrm{X}_{11}=$ Garden size & Number of hectares & Continuous & + \\
\hline $\mathrm{X}_{12}=$ Education level of the beneficiary & 1 if literate, 0 if illiterate & Dummy & + \\
\hline $\mathrm{X}_{13}=$ Household size (family labour) & Man days & Continuous & + \\
\hline $\mathrm{X}_{14}=$ Problem index & 1 if available, 0 otherwise & Dummy & - \\
\hline
\end{tabular}

Increase in the farmer's age was expected to negatively affect the profitability of vegetable production. Nwaru and Iwuji (2005) stated that entrepreneurship gradually becomes less as age of the entrepreneur increases because creativity and confidence of the entrepreneur as well as his mental capacity to cope with challenges of his business activities decrease with age. Education is thought to be important as it informs farmers on how best to strategize and adapt to better marketing conditions therefore a positive relationship was expected between education and profitability.

The amount of land cultivated under vegetables was expected to be positively allied with profitability, because the more land put under production, the higher would be the profitability of the crop because of possible economies of scale. Garden size was assumed to have a positive relationship with profitability as the bigger the garden, the more land household have to plant more vegetables hence increasing their profits. Market constraint and production constraint were set as dummy variables, where a farmer either having marketing and production constraints took the value one or no constraint took a value of zero. Both marketing and production constraints were assumes to have a negative influence on profitability of backyard gardens.

Distance between the production area and the market is expected to reduce the probability of households in participating in commercial vegetable production hence poor profits because of associated high transport costs. Therefore it is expected that market availability would positively affect profitability. Household size is assumed to have a positive relationship with 
profitability because households with large family sizes may cultivate more land. This is because family labour that is cheap is guaranteed therefore labour constraints will not be a problem.

Fertilizer quantity was measured in kilograms and was anticipated to positively affect the profitability of backyard gardening. It was assumed that the more fertilizer applied on vegetable crops up to a certain level, the more the quantity of vegetables produced. Problem index was assumed to have a negative relationship with profitability and this is because a household would spend more in-order to solve the problems that they are facing hence cutting the amount of profits realized.

Availability of alternative sources of income is also another factor that may affect the profitability of backyard gardens thus was given a value of one is alternative sources of income are available and zero otherwise. Therefore a negative relationship is expected between availability of alternative sources of income and profitability of the gardens. Major constraint to improving livelihood and threats to livelihood of the household were given value of one if they are available and zero if unavailable. Therefore, a negative relationship is expected between major constraint to improving livelihood, threats to livelihood and profitability.

\section{Results and Discussion}

\subsection{Characteristics of Respondents}

The socio economic characteristics of vegetable farmers are presented in Table 2 . The mean age of beneficiaries was 48 years with a standard deviation of 13 years. The distribution of beneficiaries by gender revealed that there were a larger proportion of females $(71 \%)$ than males (29\%). The majority of beneficiaries were single $(57 \%)$, while others were widowed (23\%), married (19\%) and divorced (1\%). Level of education was encompassed to ascertain the beneficiary's capacity to practice and understand agricultural information. People with high education level are likely to scrutinise and deduce information than those who have less education or no education at all (Martha and Aldelzadeh, 1998). The results showed that $23 \%$ of the respondents had never attended school, $49 \%$ had attained primary education, whilst $13 \%$ and $12 \%$ had gone up to junior secondary and senior secondary school respectively and $3 \%$ had tertiary education. The mean household size was 5 people. Large family size implies that beneficiaries have access to family labour and hence reduce cost of farm operations. Household size has an influence on production as it affects consumption and production (Randela, 2005). Distribution of sampled beneficiaries according to years of experience in farming revealed that on average, the beneficiaries had an experience greater than twelve months. Table 2 groups the beneficiaries according to total garden size and the majority had a garden size of $200 \mathrm{~m}^{2}$. 
Table 2. Demographic characteristics of sampled small scale vegetable farmers

\begin{tabular}{|c|c|c|c|c|}
\hline Item & & & Number of farmers $(\mathrm{N}=100)$ & Percent \\
\hline \multicolumn{5}{|c|}{ Age of farmer } \\
\hline & $21-30$ & & 12 & 12 \\
\hline & $31-40$ & & 19 & 19 \\
\hline & $41-50$ & & 31 & 31 \\
\hline & $51-60$ & & 24 & 24 \\
\hline & $61-70$ & & 11 & 11 \\
\hline & $71-80$ & & 2 & 2 \\
\hline & $81-90$ & & 1 & 1 \\
\hline & Mean & 48 & & \\
\hline & SD & 13 & & \\
\hline \multicolumn{5}{|c|}{ Gender } \\
\hline & Male & & 29 & 29 \\
\hline & Female & & 71 & 71 \\
\hline \multicolumn{5}{|c|}{ Marital status } \\
\hline & Single & & 57 & 57 \\
\hline & Married & & 19 & 19 \\
\hline & Divorced & & 1 & 1 \\
\hline & Widowed & & 23 & 23 \\
\hline \multicolumn{5}{|c|}{ Education level } \\
\hline & Never attended & & 23 & 23 \\
\hline & Primary & & 49 & 49 \\
\hline & Junior & & 13 & 13 \\
\hline & BGCSE & & 12 & 12 \\
\hline & Tertiary & & 3 & 3 \\
\hline \multicolumn{5}{|c|}{ Household size } \\
\hline & $1-4$ & & 47 & 47 \\
\hline & $5-8$ & & 38 & 38 \\
\hline & $9-12$ & & 11 & 11 \\
\hline & $13-16$ & & 3 & 3 \\
\hline & $17-20$ & & 1 & 1 \\
\hline & Mean & 5 & & \\
\hline & SD & 3 & & \\
\hline \multicolumn{5}{|c|}{ Farming experience } \\
\hline & $<9$ months & & 4 & 4 \\
\hline & 9-12 months & & 7 & 7 \\
\hline & $>12$ months & & 89 & 89 \\
\hline \multicolumn{5}{|c|}{ Garden size } \\
\hline & $100 \mathrm{~m}^{2}$ & & 20 & 20 \\
\hline & $200 \mathrm{~m}^{2}$ & & 53 & 53 \\
\hline & $300 \mathrm{~m}^{2}$ & & 27 & 27 \\
\hline
\end{tabular}




\subsection{Analysis of Production Constraints for Rural Beneficiary Households}

Farmers were asked using Focus Group Discussion (FGD) about main limitations they face during farming operations. Households were requested to list the three most important constraints they face in the gardens. Figure 1 shows the strength of each constraint in the garden. Pests and diseases seem to be the greatest challenge that $27.7 \%$ of households were facing. Farmers indicated that the problematic pests were aphids thus they were using soapy water to control them. Soapy water does not always work so households that can afford to buy pesticides were using Malathion. Households indicated that they rely on the government to supply them with pesticides but often, there are delays which lead to a build-up of pests. This is substantiated by Ellis-Jones et al. (2008) that pests and diseases have been identified as major constraints to vegetable production as they cause economic problems for vegetable farmers.

A small number of households $(4.3 \%)$ had insufficient knowledge on what to produce and when to produce for higher returns. However farmers pointed out that they grow leafy vegetables because they are perennial in nature and easy to manage. It is possible for farmers to get information by their own effort but they are facing problems due to absence of market information as most of the time they become aware of the price upon arrival at the market. Lack of water is also a major production constraint that $23 \%$ of the farmers were facing as most of them rely on rain water. Since the gardens were situated in places where access to piped water is not available, government supplies using bowsers and sometimes they go for a month without water thus disrupting vegetable production. For farmers (4\%) who pointed out that they use piped water for irrigation, their water bills exponentially increased and they could not afford to pay the bill hence their water was be disconnected. Rahman et al. (2008) identified shortage of irrigation water in the dry season, lack of quality seeds, lack of knowledge on vegetable production and preservation, insect/pest problems on vegetables as major constraints to homestead vegetable production for sale.

Damage of gardens by domestic animals affected $3.3 \%$ of the farmers. Goats and donkeys could damage the net shading and eat the vegetables inside. As a way of preventing animals from damaging their gardens, farmers have put up fences to surround the gardens. About $2.3 \%$ of the farmers had a problem of vandalism and crime as their gardens were destroyed and the thieves took the poles thus leaving the net shading sagging. These findings are supported by Chowdhuri et al. (2014) that farmers pointed out they have a problem of vegetable damage by domestic animals and loss of production due to theft. Low quality of materials supplied (variable inputs included) was identified by $15.7 \%$ of the farmers as a production constraint. For example, farmers indicated that they were given pipes for drip irrigation that were blocked and were never checked thus the farmers have never used them and some were given leaking water tanks so they could not store water in them until they could fix the leaks. The farmers indicated that though they would like to fix the leaks themselves it is not possible as they cannot afford to do so. Chowdhuri et al. (2014) found that inadequate supply of good quality seeds was also a vegetable production problem faced by farmers. 


\section{$\triangle$ Macrothink}

Transport was a production constraint to $2 \%$ of the farmers as they did not have reliable transport to the market or even to places where they can purchase inputs they needed. Kiros, (2008) found that the issue of transport brings into focus the inadequacy of farm roads and the poor condition of existing ones as most of the production sites are in rural areas. Because soil testing was not done before the farmer was given the backyard gardens, $4.3 \%$ of the farmers indicated that where the gardens were constructed was not suitable for growing vegetables and thus gardens failed. Soil properties and its water permeability should be known as they are important aspects of vegetable growth and quality (Nichols \& Hilmi, 2009).

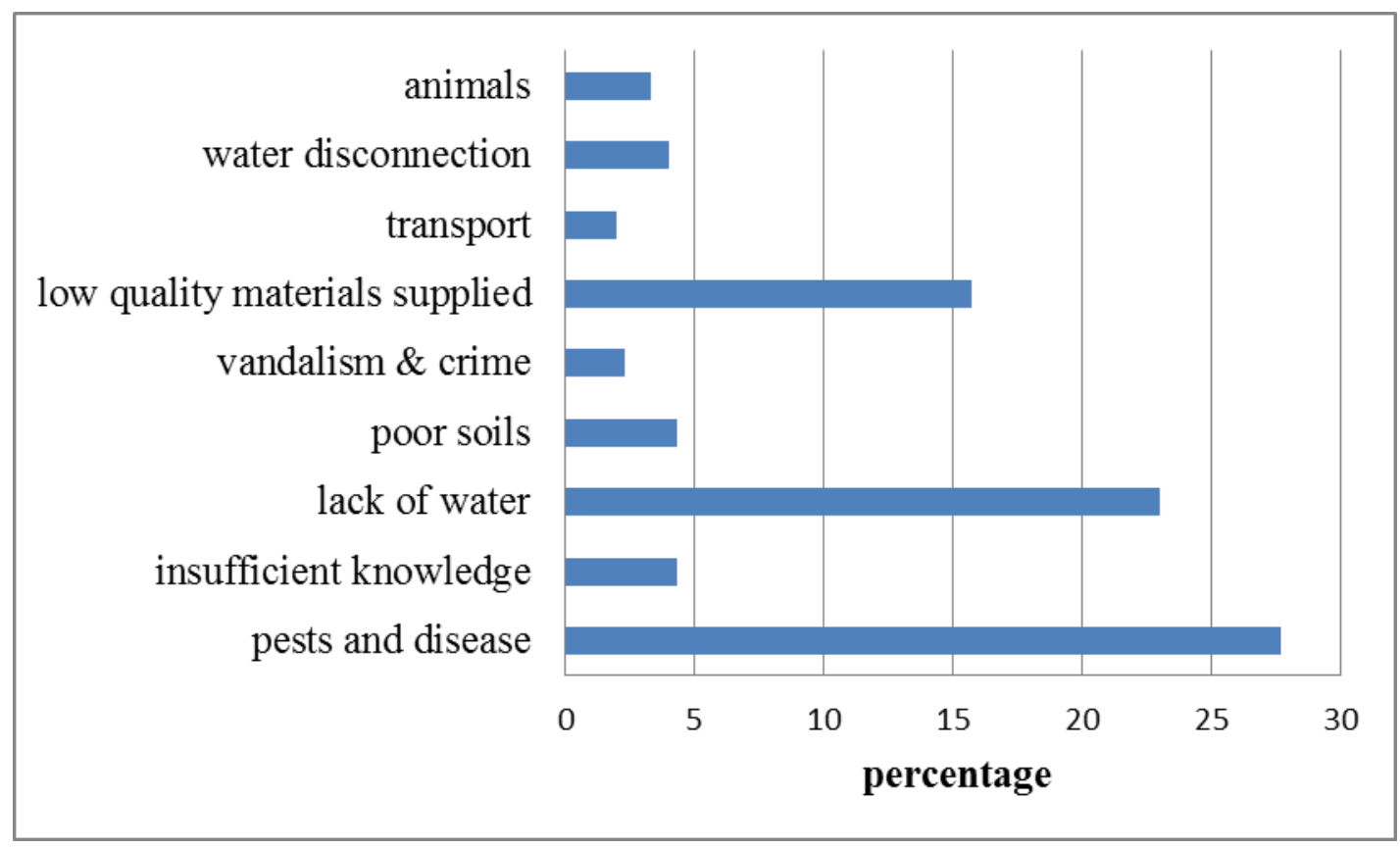

Figure 1. Production constraints

\subsection{Analysis of Marketing Constraints}

Results of marketing constraints facing backyard gardens are presented in Figure 2. In marketing of horticultural produce, lack of market was identified by the majority (26\%) as the main constraint. The primary markets for various vegetable products from the gardens were neighborhood households who buy for consumption. Likewise, vendors who bought in bulk for re-sale in open markets served as another outlet. Xaba and Masuku (2013) found out that some vegetables produced by farmers in Swaziland were spoiled due to lack of markets.

Lack of storage facilities was a problem faced by $11 \%$ of the farmers as sometimes they produced excess vegetables which they could not consume. Large amounts of vegetables were lost due to wastage as farmers had no technical knowledge of preservation and lack of facilities. This led to high post-harvest losses because of large amounts of left overs. Lack of market facility was identified by $20 \%$ of the farmers as a constraint because they sold their vegetables in the local market as they were dependent on word of mouth to market their gardens. As a result, they did not get good prices. Poor prices were encountered by $15.7 \%$ of the farmers. The main cause is that farmers produce at the same time leading to low demand 


\section{Macrothink}

because there might not be enough market to sell (Antwi and Seahlodi, 2011; Kiros, 2008).

Salami et al. (2010) stated that road systems are the most serious infrastructural bottleneck facing agricultural development. Results in Figure 2 show that $4.7 \%$ of beneficiaries were inhibited by the lack or poor access roads. These may have limited transportation of vegetables to better or other markets. Therefore, it may have also delayed quick distribution of produce after harvesting hence the vegetables deteriorated. Access to transport by farmers plays a significant role in their ability to access markets. Since vegetables are highly perishable, there is a sense of urgency in marketing these products as quickly and efficiently as possible in order to maintain their farm fresh value. About $6.7 \%$ of the farmers did not have access to convenient modern transportation system to ship their products to the market thus they were forced to hire transport from other people or use public transport. The problem of marketing constraints arise due to many factors such as limited knowledge, lack of access to reliable markets and lack of appropriate and affordable means of transport (Chanimuka et al., 2008).

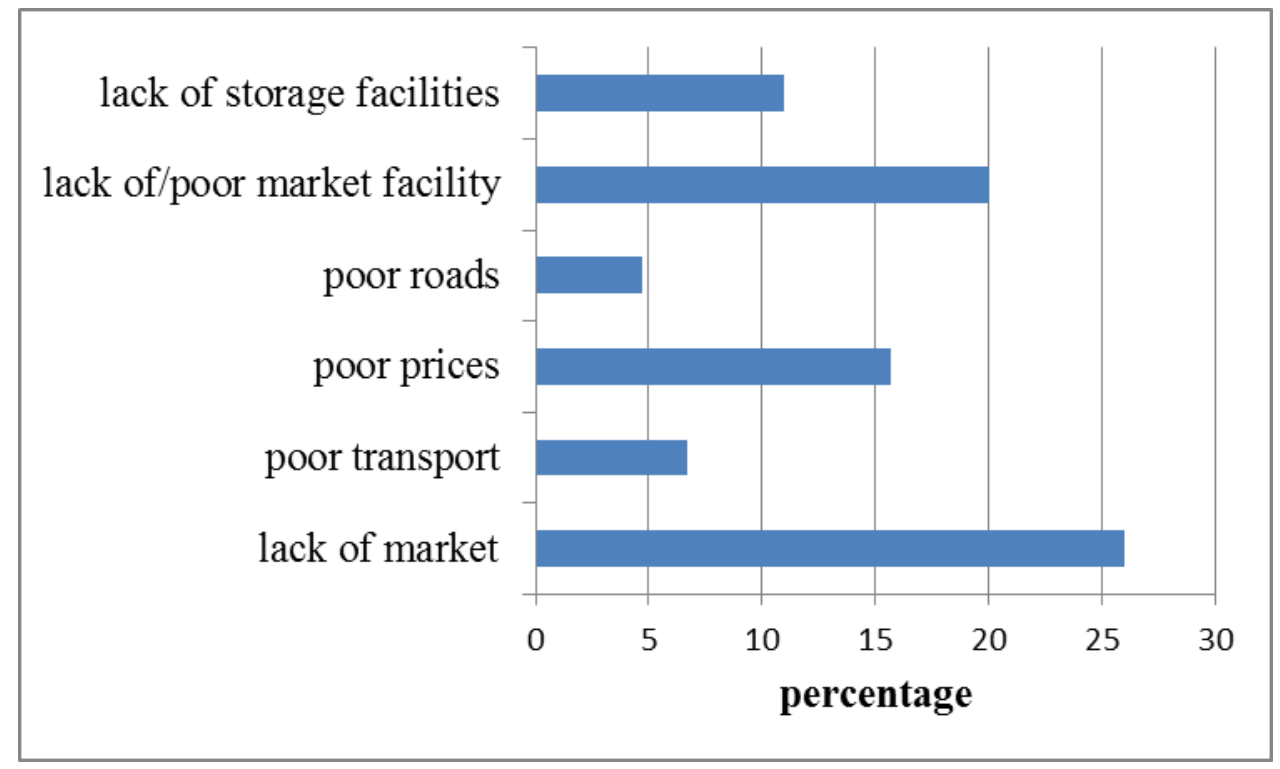

Figure 2. Marketing constraints

\subsection{Gross Margin Analysis}

Table 3 summarizes the yield, cost of variable inputs (TVC) and gross margins (GM) per hectare (ha) by gardening activities. In these calculations, household level margins per hectare were extrapolated from farmed area. Gross margins are calculated by deducting costs (fertilizers, chemicals, seed and labour) from the value of total production of each individual household then averages are taken for each factor. Also given in Table 3 is a comparison of the different garden crops and farm level profits on per hectare basis. 
Table 3. Gross margin analysis of garden crops

\begin{tabular}{|l|l|l|l|l|l|l|l|}
\hline & Leafy vegetables & Onions & Tomatoes & Green pepper & Carrots & Beetroot & Cabbage \\
\hline Yield (t/ha) & 7.95 & 14.26 & 7.11 & 33.29 & 35.94 & 62.60 & 15 \\
\hline Average area under crop (ha) & 0.294 & 0.046 & 0.109 & 0.034 & 0.016 & 0.025 & 0.002 \\
\hline Gross income per ha (US\$/ha) & 11607.84 & 6221.55 & 6365.19 & 6459.04 & 21871.44 & 45784.39 & 14550 \\
\hline TVC per ha (US\$/ha) & 3218.36 & 3812.20 & 4776.21 & 4713.06 & 4410.47 & 4748.81 & 5820 \\
\hline GM per ha (US\$/ha) & 8389.47 & 2409.33 & 1588.99 & 1746 & 17460.97 & 41035.58 & 5820 \\
\hline GM per TVC & 2.61 & 0.63 & 0.33 & 0.37 & 3.96 & 8.64 & 1 \\
\hline
\end{tabular}

All the garden crops analysed had positive gross margins. However, of the seven main crops analysed beetroots had the highest gross margin as well as the highest return on Pula spent, followed by carrots and leafy vegetables. The fact that leafy vegetables are in high demand both locally and urban markets can be used to explain why their gross margin was high. With tomatoes, onions and green pepper, they are additives to the relish dish such that in case of financial crises one can forgo them.

From the results, gardening is viable as indicated by the gross margins. The mean gross margin per hectare for the leafy vegetables was US\$8 389.47, onions was US\$2 409.33, US\$1 588.99 for tomatoes, carrots was US\$17 460.97, beetroots was US\$41 035.58 and cabbage was US\$5 820. On average, the area under leafy vegetables was 0.294 ha, onions were 0.0458ha, 0.1091ha for tomatoes, carrots had 0.016ha, beetroots and cabbages had 0.025 ha and 0.002 ha respectively. Larger areas could significantly increase the contribution of income from the garden to the total household income.

\subsection{Factors Affecting Gross Margin per Hectare}

Gross margin is a function of price and yield. Assuming a constant price, it is expected that yield will cause the variation in the gross margins across rural beneficiary households. Yield is affected by household characteristics, input usage and garden size among other factors. The results of log-linear analysis of these relationships are presented in Table 4. The amount of fertilizer applied was significant at $1 \%$. Fertilizer is an agent for increasing yields and when optimum levels are applied, more output is realized and thus gross margins. Results showed that a one unit increase of fertilizer raises yield of vegetables by $70 \%$. This is corroborated by Chellemi and Pierce (2002) that supplemental use of fertilizers an significantly impact marketable yields as fertilizer application increased the marketable yield of the first harvest. The head of a household is assumed to be responsible for the coordination of the household activities therefore, age of the household head is often indicative of farming experience as well as the ability to comprehend new technologies. The results in Table 4 show that age has a negative relationship with vegetable yields. When the age of the household head increases by one unit then yield will be reduce by $7 \%$. This is because the innovativeness, buoyancy of the farmer and mental abilities to deal with challenges that arise decreases with age.

Nichols and Hilmi (2009) found that availability of market research enables smallholder farmers to become more knowledgeable about prices, what vegetables are wanted and the quantities of the vegetables markets require. Therefore, availability of market was significant 
at $1 \%$ and the positive coefficient can be construed to mean when farmers have a particular preference they get motivated to increase yields and thus increasing profits. There is often preference for retail markets because they tend to provide higher prices as observed by Oxouzi \& Papanagiotou (2010). The results suggest a positive relationship between the yield and area devoted to vegetable production due to economies of scale. Area planted was significant at $10 \%$ which can be inferred to mean that a unit increase in the area planted will increase yield and consequently gross margins by 34\%. Given good management practices, increase in area under vegetable production would increase output. Erbaugh et al. (2008) found that farm size negatively influenced gross margins and this contrasted the results found by Sulumbe et al. (2010) who found positive relationships between gross margins and farm size.

The alternative income source of a household is another factor that was found to affect profitability of the gardens negatively. When a household has an alternative source of income, it reduces gross margins by $3 \%$. With existence of other sources of income, there is tendency of less concentration on the gardens leading to lower yields assuming constant prices, low output leads to low margins. Even though the source of labour dummy was not significant in explaining the observed gross margins, household size was significant at $10 \%$ and showed a negative relationship between household size and yield. The observed relationship may be due to the fact that in some instances, despite the relatively large household size, most members spend their time on other activities and thus may not represent a readily available labour source. Despite a large household size, profitability may be negatively impacted in that some family members may not take part in production activities or due to diminishing marginal returns to labour (Ahuja, 2000).

Table 4. Factors affecting gross margin per hectare

\begin{tabular}{llll}
\hline Variable & Coefficient & Std. Err. & $\mathrm{t}$ \\
\hline Age & -0.07 & 0.30 & -0.23 \\
Fertilizer & 0.70 & 0.14 & $5.10^{* * *}$ \\
Area & 0.34 & 0.18 & $1.87^{*}$ \\
Income source & -0.03 & 0.05 & -1.70 \\
Constraint & -0.08 & 0.07 & -1.30 \\
Threat & 0.003 & 0.03 & 0.09 \\
Labour source & 0.001 & 0.63 & -0.00 \\
Market constraint & 0.05 & 0.03 & 1.31 \\
Production constraint & 0.17 & 0.06 & $3.06^{* * *}$ \\
Market & 0.63 & 0.22 & $2.79^{* * *}$ \\
Garden size & -0.19 & 0.17 & -1.13 \\
Education & 0.11 & 0.11 & 1.06 \\
Household size & -0.05 & 0.03 & $-1.79^{*}$ \\
Problem index & -0.29 & 0.27 & -1.11 \\
Constant & 0.50 & 1.97 & 0.25 \\
R-squared & $=0.5456$ & & \\
Adjusted R-squared & $=0.4521$ & & \\
$* * *$ : refers to significance at $10 \%, 5 \%$ and $1 \%$ level, respectively
\end{tabular}




\section{Conclusion and Recommendations}

This study examined profitability, factors affecting profitability, production and marketing constraints of backyard gardening. The study showed that backyard gardening is viable as the vegetables that were investigated had positive gross margins. Profitability of vegetables was influenced by amount of fertilizer applied, area planted, production constraint, market availability and household size while age of household head and alternative source of income negatively affected profitability. Various production and marketing constraints faced by farmers were pests and diseases, lack of water, low quality materials supplied, lack of market, lack of storage facilities, lack of market facilities and poor prices.

Therefore, beneficiaries should form production groups or cooperatives to improve their market share. Each group should have a committee trained in various aspects of marketing and be able to have updated pricing information that will be availed to beneficiaries in time. Program leaders should develop policies aimed at enhancing productivity of small scale vegetable production through provision of workshops whereby beneficiaries would acquire more training on vegetable production. This would empower beneficiaries to be more productive hence improving their profitability. Further research on how Agricultural Extension Agents can assist beneficiaries of the program is therefore necessary.

\section{Acknowledgement}

The research is financed by German Academic Exchange Service - Deutscher Akadamischer Austauscdienst (DAAD) through African Economic Research Consortium (AERC). My sincere gratitude goes to Prof. J.K Lagat and Dr. N.M Tselaesele for their assistance.

\section{References}

Adeyemo, R., Oke, J. T. ., \& Akinola, A. A. (2010). Economic Efficiency of Small Scale Farmers in Ogun State , Nigeria. Journal of Tropicultura, 28(2), 84-88.

Ahmad, B., Hassan, S., \& Bakhsh, K. (2005). Factors Affecting Yield and Profitability of Carrot in Two Districts of Punjab. Internatioanl Journal of Agriculture and Biology, 7(5), 794-798.

Ahuja, G. (2000). The duality of collaboration. Strategic Management Journal, 21(3), 317-343.

Antwi, M., \& Seahlodi, P. (2011). Marketing Constraints Facing Emerging Small-Scale Pig Farmers in Gauteng Province, South Africa. Journal of Human Ecology, 36(1), 37-42.

Bagamba, F., Ssenyonga, J. W., Tushemereirwe, W. K., \& Gold, C. S. (1998). Performance and profitability of the banana sub-sector in Uganda farming systems. In C. Picq, E. Foure, \& E. . Frison (Eds.), Bananas and Food Security (pp. 729-739). Montpellier: INIBAP.

Basimane, I. (2014). Backyard gardening: Just what the doctor ordered. Retrieved from www.kutlwano.gov.bw/kut-article-teaser-detail.Php $?$ aid = 54andcid=26andmid=60

Chanimuka, P., Senyolo, G. M., Makhura, M. N., \& Belete, A. (2008). A factor analysis of 
access to and use of service infrastructure amongst emerging farmers in South Africa. Agrekon, 47(3), 37-41. http://doi.org/10.1080/03031853.2008.9523805

Chellemi, D. O., \& Pierce, F. (2002). Effect of organic fertilizer applications on growth , yield and pests of vegetable crops. Florida State Horticultural Society, 115, 315-321.

Chowdhuri, N. Y., Haque, S., Shammi, S. A., Jannat, A., \& Sannyashi, P. R. (2014). Profitability analysis of winter vegetables production in a selected area of narshingdi district in Bangladesh. Progressive Agriculture, 25, 47-53.

Ellis-Jones, J., J. Stenhouse, H. Gridley, J. Hellaand, and M. Onim. 2008. Baseline study on vegetable production and marketing. Vegetable breeding and seed systems for poverty reduction in Africa.

Erbaugh, D. (2008). Profitability analysis of sorghum framing and its influence on sorghum value chain in Tanzania: A case study of Singida and Simanjaro. Tanzania.

Forestry, A. F. (2009). Farm Gross margins. State Governemnt of Victoria

Kiros, A. (2008). Opportunities and Challenges of Vegetable Marketing in Kilte-Awlaelo Woreda. Unpublished Masters Thesis. Mekelle University.

Maipose, G. S. (2008). Policy and Institutional Dynamics of Sustained Development in Botswana. The Commision of Growth and Development No. 35.

Ministry of presidential affairs and public administration (2015) state of the nation address by his Excellency. Gaborone, Botswana. (http://www.gov.bw/en/News/N1_News_211/)

Nichols, M., \& Hilmi, M. (2009). Growing vegetables for home and market. Diversification booklet 11, Rome.

Nwaru, J. C., \& Iwuji, O. (2005). Marketing margins and their determinants in plantain marketing in Owerri agricultural zone of Imo State, Nigeria. In A. M. Orheruata, S.O. Nwokoro, M.T. Ajayi, A. T. Adekunle,, \& G.N. Asumugha, Agricultural Rebirth for Improved Production in Nigeria (eds.), In proceedings of the $39^{\text {th }}$ Annual onference of the Agricultural Society of Nigeria, University of Benin, Benin City, Nigeria, 385-387.

Ojo, S. O. (2009). Backyard Farming: A Panacea for Food Security in Nigeria. Journal of Human Ecology, 28(2), 127-133.

Oxouzi, E., \& Papanagiotou, E. (2010). Comparative analysis of organic and conventional farmers and their farming systems. Where does the difference lie? Bulgarian Journal of Agricultural Science, 16(2), 135-142.

Rahman, F. M. M., Mortuza, M. G. G., Rahman, M. T., \& Rokonuzzaman, M. (2008). Food security through homestead vegetable production in the smallholder agricultural improvement project ( SAIP ) area. J. Bangladesh Agril. Univ., 6(2), 261-269. http://doi.org/10.3329/jbau.v6i2.4820

Rural Solutions South Australia. (2015). Farm Gross Margin Guide. South Australia. 
Salami, A., Kamara, A. B., Abdul, B., \& John, C. (2010). Smallholder Agriculture in East Africa: Trends, Constraints and Opportunities. Working paper series No. 105.

Statistics Botswana (2010). Botswana Core Welfare Indicators Survey. (2009-2010). Government printer. Gaborone. Botswana

Sulumbe MI, Iheanacho AC, Mohammed ST (2010). Profitability Analysis of cotton production Under Sole-cropping system In Adamawa State, Nigeria. Journal of Sustainable Development Agriculture Environment, 5 (1): 7-13.

Torimiro, D. O., Tselaesele, N. T., Seven, K., Ramorathudi, M. V., \& Hulela, K. (2015). Vulnerable Groups' Involvement in Small-scale Vegetable Production: A Panacea for Poverty and Food Insecurity? International Journal of Vegetable Science, 1-9. http://doi.org/10.1080/19315260.2014.945632

Xaba, B. G., \& Masuku, M. B. (2013). Factors Affecting the Productivity and Profitability of Vegetables Production in Swaziland. Journal of Agricultural Studies, 1(2), 37-52. http://doi.org/10.5296/jas.v1i2.3748

Yamane, T. (1973). Statistics: An Introductory Analysis, 2nd Ed., New York: Harper and Row.

\section{Copyright Disclaimer}

Copyright for this article is retained by the author(s), with first publication rights granted to the journal.

This is an open-access article distributed under the terms and conditions of the Creative Commons Attribution license (http://creativecommons.org/licenses/by/4.0/). 